\title{
Risk Factors for the Incidence of Stunting in Senggi Public Health Center, Keerom, Papua 2015
}

\author{
Gutit Enny Susanti ${ }^{1}$, Berliana Tampubolon ${ }^{2}$, Agussalim $^{3}$ \\ ${ }^{1,2,3}$ Poltekkes Kemenkes Jayapura, Papua, Indonesia
}

\begin{abstract}
Background: In the province of Papua Stunting prevalence of 40.1\%, in Keerom district amounted to 42.3\%. The aim of this study was to analyze the risk factors for the incidence of stunting in children (1-5 years) in Puskesmas Senggi, Keerom. Methods: observational, case-control study design, a retrospective approach. Populations of all children under the age of 1-5 years, samples of infant cases of stunting (value ZscoreHight /Age and or Lenght / Age <- 2 SD) as a screening, not a toddler control stunting with ratio 1: 2. Respondents (Mother toddlers) cases of stunting and not stunting (control) was taken by random sampling. Data collection techniques interview, the data collected by the nutritional intake of food recall $1 \times 24$ hours. Data processed manually, nutrition processed nutrisurvei program, anthropometric data with the WHO program-Antro 2005. Statistical analysis with the program "SPSS" and presented in tables and explanations. Results: The results showed Stunting Case for 33.3\%, $66.7 \%$ not stunting,. History of eating while pregnant women in the case group less $65.6 \%$, a history of gift weaning less than $62.5 \%$, a history of exclusive breastfeeding $68.8 \%$, a history of infectious diseases $75 \%$, the nutritional intake of less than $68.8 \%$, the status of incomplete immunization $59.4 \%$ and the economic status of the family low 75\%. There is a relationship history of eating the mother during pregnancy, a history of exclusive breastfeeding, history of gift weaning food, a history of infectious disease, nutrition, immunization, economic with the incidence of stunting each $P$ value of $<0.05$, OR $>1$, while a history of giving Asi exclusive OR value $<1$. Conclusions, stunting incidence of risk factors associated with a history of eating nutritious from prenatal and breastfeeding history, history of gift weaning, disease history, immunization and supported by adequate economic condition
\end{abstract}

Keywords: Risk Factors Stunting, Toddler

\section{Background}

Nutritional problems can occur in all age groups, namely pregnant women, infants, toddlers, adults and the elderly. Nutrition is a major concern specifically at these groups, because it can support in maintaining and improving health and nutrition, particularly for pregnant women, infants and toddlers can support the growth and development to be optimized. A period of one to five years of age is a critical period, as the initerjadi period of rapid growth and development (Kurniasih, et al, 2010).

One of the problems of malnutrition is stunting that often occurs in infants. Stunting in children is the result of longterm food consumption as a result of chronic nutritional quality that does not comply with the requirements in combination with the morbidity of infectious diseases and environmental problems (Semba et.al, 2008). UNICEF, 2010 , suggests that stunting is a chronic condition that describes the inhibition of the growth of long-term malnutrition. Stunting according to WHO Child Growth Standards are based on the length of the index weight or height according to a age (Lenght /Age or Hight /Age ) with a limit value Zscore $<$ than - 2 SD.

The Lancet's report in 2008, in the world there are 178 million children aged less than five years old who suffer from stunting. In Indonesia, the trend of the incidence of stunting among children under five do not show significant changes. Riskesdas data in 2013 showed the prevalence of stunting in Indonesia amounted to $37.2 \%$. According to the WHO to issue stunting or stands at $20 \%$, mala every province in Indonesia is still in a state of public health problems. While the prevalence of stunting or short in Papua province, according to data Riskesdas in 2013 amounted to $40.1 \%$, in Keerom by $42.8 \%$. (MoH RI, 2013).
Basically stunting nutritional status can be affected by factors directly and indirectly and the root of the problem (UNICEF, 1990). Factors directly related to stunting in the form of nutrient intake daily food and health status. Energy intake showed a significant relationship to the incidence of stunting as fditelitin by Fitri (2012). Besides participating projuga intake contributes to the incidence of stunting, research Stephenson et.al (2010) states that children aged 25 years in Kenya and Nigeria adequacy of protein intake is not associated with the incidence of stunting. Similar study also found that dietary intake and health status related to the significance of the nutritional status of stunting in children in Libya (Taguri, et.al, 2007). Then the health status such as infectious diseases have a positive relationship to the index of the nutritional status of TB / U (Masithah, et al, (2005).

According Semba and Bloem, (2001) that parenting, health care and domestic environment is an indirect factor as well as the root of the problem which includes residential and economic status turns giving relationship with poor nutritional status. Patterns of care in the form of exclusive breastfeeding contributes to the incidence of stunting (Oktavia, 2011).

Neldawati research results, (2006) found the immunization status of children under five is one indicator of contact with the health service. Immunization status has a significant correlation with the index of the nutritional status of Hight / Age. This is in line with research Milman, et.al, 1, (2005) and Taguri, et.al, (2006), that the immunization status has a significant relationship with the occurrence of stunting in children under five.

Based on the background of the above problems, the researchers are interested in doing research on risk factors 


\section{International Journal of Science and Research (IJSR) \\ ISSN (Online): 2319-7064}

Index Copernicus Value (2013): 6.14 | Impact Factor (2015): 6.391

for the incidence of stunting in Public health center Senggi, Keerom.

\section{Problem Formulation}

In Indonesian, the incidence of stunting in children under five do not show a significant decline. Based on data Riskesdas in 2013 in Papua Province showed the prevalence of stunting above the national as well as in Keerom $(\mathrm{MoH}$ RI, 2013).

In general, the factors that influence the incidence of stunting is very complex, the formulation of research problems is "if there is the influence of a history of eating during pregnancy, a history of exclusive breastfeeding, history of administration of weaning food, intake of nutrition, history of infectious diseases, economic status, immunization status with the incidence of stunting? "

\section{Objective}

\section{1) General Purpose}

To analyze the risk factors for the incidence of stunting in children (1-5 years) in PuskesmasSenggi, Keerom.

\section{2) Special Purpose}

a) Describe the sample characteristics (age, education, occupation, number of family members) in Public health centerSenggi, Keerom

b) Describe Stunting in children under five in Public health centerSenggi, Keerom

c) c.Describe the history of eating while pregnant women, a history of exclusive breastfeeding, complementary feeding Giving history, history of infectious disease, nutrition, family economic status, the status of immunization in infants in Public health centerSenggi, Keerom.

d) Knowing the relationship between a history of eating while pregnant with the incidence of stunting in children under five in Public helath centerSenggi, Keerom

e) The relationship between the history of exclusive breastfeeding with the incidence of stunting in children under five in Public health centerSenggi, Keerom

f) The relationship between the history of gift weaning with events Stunting in children under five in Public health centerSenggi, Keerom

g) The relationship between the history of infectious disease with the incidence of stunting in children under five in Public health centerSenggi, Keerom

h) Analyzing the relationship between nutrient intake with the incidence of stunting in children under five in Public health center Senggi, Keerom

i) The relationship between the economic status of families with events Stunting in children under five in Public health centerSenggi, Keerom

j) The relationship between the immunization status of children under five with the incidence of stunting in children under five in Public health center Senggi, Keerom.

\section{3) Benefits Research}

The result is expected to provide benefits for: a) Keerom District Health Office as a useful input for determining the efforts of handling stunting is more effective in the future

b) Results are expected to be used as information material like the researchers who want to investigate the problem further Stunting and deeper

c) As inputs for policy makers or the person in charge of the program for planning program providing food for pregnant women

d) The research result can be the subject of study / reference for the parties concerned, especially for policy makers to be able to reduce the number of Stunting

\section{Research Methods}

\section{1) Study Design}

This type of research is observational research with case control study that used retrospective approach to research that follows the course of the disease process towards the back in chronological order(Hasmi, 2012). In this observational study carried out by following the journey of consequence to the cause as well as to compare the amount of exposure to risk factors in the past between the cases with controls for comparison. The study design as figure 4below

\section{2) Place and Time Research}

Location study in PHCSenggi, Keerom, research was carried out for two months in 2015

\section{3) Population and Sample}

The population is families with toddlers and young children aged 1-5 years in Public health centerSenggi, Jayapura district. The target population in this study were all children under the age of 1-5 years in Keerom, while affordable population is all children aged 1-5 years in Public health centerSenggi, Keerom. Subjects or samples in this study were all selected cases and controls with a comparison between cases and controls 1: 2 . The cases were children aged 1-5 years with the index Z-Score Hight / Age or Lenght / Age for $\leq-2 \mathrm{SD}$, while control is children aged 1-5 years with the index Lenght / Age or Hight / Age amounted to - 2 $\mathrm{SD}$ to $+2 \mathrm{SD}$. Respondents in this study is the toddler's mother who was elected to the subject or sample. So in this study conducted screening of nutritional status in order to get a case of stunting, with an estimated sample size of at least 30 children. And a control sample 60 children. So the total sample of cases and controls amounted to 90 children and 90 respondents. While the sampling technique controls carried out by random sampling.

\section{4) Variable Research}

The dependent variable in this research is stunting, while the independent variable is a history of eating during pregnancy, exclusive breastfeeding history, history of gift weaning food, a history of infections, intake of nutrients (energy, protein), immunization status, economic status.

\section{5) Types and Data Collection Techniques}

\section{a) Primary Data}

Primary data includes history of eating during pregnancy, exclusive breastfeeding history, history of gift weaning, immunization status, economic status of the family gathered in interviews with rock questionnaire. Data 


\section{International Journal of Science and Research (IJSR) \\ ISSN (Online): 2319-7064}

Index Copernicus Value (2013): 6.14 | Impact Factor (2015): 6.391

intake of nutrients (energy, protein is collected by the method of food recall $1 \times 24$ hours over 2 days are not consecutive - succession. While the data collected stunting anthropometric measurements and body length or height.

b) Secondary Data

Sekundert Data collected include health centers statistics include a general overview of the health center Senggi, population and other data that support the research.

\section{6) Research Instrument}

The research instruments used were:

\section{a) Microtoice}

Microtoice used to measure the height of children older than 2 years with accuracy of $0.1 \mathrm{~cm}$. Furthermore, children aged $<2$ years tool used to measure the height is Langboard, accuracy of $0.1 \mathrm{~cm}$. Furthermore, the measurement results were processed using the software, to see the nutritional status based on standards WHO2005 (Z-Score Higth / Age orLenght /Age).

b) Questionnaires

Used a questionnaire containing questions to be asked of mothers. Questions include data about the characteristics of the toddler as age, sex, body length and birth weight, immunization status. Respondent characteristics include; age, education, occupation, income in a month, the number of biological children, junlah family members lived one house. Questions about the history of eating during pregnancy, exclusive breastfeeding history, history of gift weaning, disease history that ever suffered.Food recall questionnaire sheet, then the data intake of processed using software with Nutri survey program.

\section{7) Processing, Analysis and Presentation of Data}

\section{a) Data Processing}

The data collected in this study further processed manually through the following steps:

\section{- Anthropometric data processing (data screening)}

Anthropometric data processing based on the results of measurements of the child's height, processed to determine the value of Zscore. Zscore value on anthropometric indices height for age (Hight / Age) will show the status of nutrition in a state of stunting or not. Zscore value will be calculated using the WHO-2005 standards

\section{- Data processing nutrition in children under five} Data processing daily food intake (breakfast until dinner) obtained from food recall $1 \times 24$, then processed using software with nutrisurvey program.

- Complete immunization data processing toddler Processing of immunization data obtained from the records of immunization in health card (The Card Healthy) and a register book Posyandu toddler ageappropriate, and then grouped into the category yes (complete) or incomplete.

\section{- History Data processing Mothers Eat While Pregnant} Eating history data obtained from the mother during pregnancy questionnaire answers that include the type of food, the frequency of meals in a day, the amount eaten, there is no prohibition or eating, or not there is an eating disorder because of pregnancy, then grouped into either category and or less
- History Data processing Exclusive Breastfeeding

History data of exclusive breastfeeding in infants is obtained based on the recognition of mothers of the questionnaire as recommended (0-6 months) without provision of other beverages, including water, then grouped into yes or no exclusive breastfeeding

- History Data processing granting complementary feeding in infants

Data history of gift weaning in infants obtained by the recognition of mothers of questionnaires, then grouped into yes or no as recommended in the guidelines of gift weaning from the $\mathrm{MOH}$. Furthermore grouped into categories corresponding yes or no.

- History Data processing Infectious Diseases

Data history of infectious diseases in infants when the mother is still pregnant and infectious diseases in children as babies up to 3 months prior to the study, obtained by the recognition of mothers of the questionnaire. Then the data is grouped into yes or no history of infectious diseases

- Processing of Family Economic Status

Family economic status data obtained from the sum total income of family members per month, then divided by the number of members in the family, so that the data is known income / capita as compared according to the poverty line of BPS Papua

\section{b) Encodes the data (data coding)}

At this stage of the activities carried out is to provide a code on the data available, then mengklasifikasdikan data according to the needs of research. Before dropping to lepangan for data retrieval, researchers and other data collectors in terms of the perception of technical interviews and questionnaires.

\section{c) Data Analysis}

\section{- Univariate analysis}

Analysis in use to see the picture of the frequency distribution of each of the variables studied, both the dependent variable (stunting) and independent (a history of eating during pregnancy, a history of breastfeeding teksklusif, history of gift weaning, disease history, intake of nutrition, immunization status, economic status family, toddlers characteristics and the characteristics of the respondents). The data generated can be katagorik according to the measurement results contained in the operational defisi.

\section{- Analysis Bevariat}

This analysis is used to examine the relationship between the dependent and independent variables. Data generated in the study will be grouped so as to produce the data katagorik. At bevariat analyzes each independent variable cross-tabulated with the dependent variable. In the $2 \times 2$ cross tabulations will look for value Odds ratio (OR) to determine whether there is a relationship between the dependent and independent variables. They will also be carried out analysis of statistical tests "Chi Square" to determine the significance relationship between the dependent and independent variables, if the $p$ value $<0.05$ means that there is a statistically significant relationship. Analysis of statistical tests "Chi Square" selected in accordance with one of the uses for testing the 


\section{International Journal of Science and Research (IJSR) \\ ISSN (Online): 2319-7064}

Index Copernicus Value (2013): 6.14 | Impact Factor (2015): 6.391

independence between two variables (Sabri\&Hastono, 2008).

\section{8) Hypothesis}

a) Ho:

- There is no relationship history of eating while pregnant with events Stunting in children under five in Public health center Senggi, Keerom

- There is no relationship history with the incidence of exclusive breastfeeding in infants Stunting in Public health center Senggi, Keerom

- There is no relationship history of gift weaning with incidence Stunting in children under five in Public health center Senggi, Keerom

- No correlation history of infectious disease with the incidence of Stunting in Toddlers at PuskesmasSenggi, Keerom

- No relationship nutrition (energy, protein) with the incidence of stunting in childrenunder five in PuskesmasSenggi, Keerom

- There is no immunization status relationship with the incidence of stunting in children under fivein SenggiPublic health center, Keerom

- There is no correlation with the incidence of family economic status of stunting in children under five in the region of PuskesmasSenggi, Keerom

\section{b) Ha:}

- There is a history of relationship eating while pregnant with events Stunting in children under five in Public health center Senggi, Keerom

- There is a history of relationship with the incidence of exclusive breastfeeding in infants Stunting in Public health center Senggi, Keerom

- There is a history of the relationship of gift weaning with Genesis Stunting in children under five in Public health center Senggi, Keerom

- There is a history of relationship with the incidence of infectious diseases in Toddlers Stunting in Public health center,Keerom

- There is a relationship nutrition (energy, protein) with the incidence of Stunting in childrenunder five in Public health centerSenggi, Keerom

- There immunization status relationship with the incidence of stunting in children under five in the region of Public health center Senggi, Keerom

- There is a relationship with the incidence of family economic status Stunting in Toddlers at Public health center Senggi, Keerom.

\section{9) Operational Definition and Criteria}

\section{Objective}

1. History of eating during pregnancy in this study is the recognition of the mother about the type, frequency and the number of daily meals in pregnancy as recommended, whether there is a taboo against eating types, presence or absence of the eating disorder because of her pregnancy, as measured by questionnaire

\section{Objective criteria:}

Good = If eating diverse type, frequency of at least 3 times, the amount in accordance with the recommendation and there are no restrictions on food

Less $=$ if not a variety of food types, frequency, three times less than the recommended amount, and no restrictions on food or any of the above is not appropriate

2. History of exclusive breastfeeding in this study is the recognition of the mother when the child is still a baby is given breast milk alone from the age of 0-6 months, without given any food or drink, including water that is measured by questionnaires

\section{Objective criteria:}

Yes $=$ if the current toddlers aged 0-6 months of breastfeeding mothers withoutgiven additional food / drink anything.

Not $=$ if a toddler when the baby is breastfed less than the age of 6 month

3. History of Giving breast milk in this study is the recognition of the mother giving complementary foods when infants aged over 6 months either from your local grocery or food ingredients manufacturer that is processed and given by her mother in accordance with the guidelines recommended by the provision of food, measured by questionnaire.

\section{Objective criteria:}

Yes $=$ if feeding complementary feeding in infants above the age of 6 months and in accordance with the recommendation Not $=$ if feeding complementary feeding in infants is not in accordance with the age and not in accordance with the recommendation

4. History of infectious disease in this study is the recognition of the mother of diseases never suffered by the mother during pregnancy infants and toddlers history of illness since the age of infants up to 3 months prior to the study, how often sick, kind of disease that often affects.

\section{Objective criteria:}

Yes $=$ if pregnancy was never sick infants, $\geq 3$ times during pregnancy, the baby had been ill, thelast 3 months have been ill infants, the frequency often

No $=$ not been sick during pregnancy, the baby is not sick, not sick last 3 months

5. Dietary intake in this study is the number of energy and protein from food eaten by toddlers in a day as measured by the method of food recall 1 x 24 hours for 1 day, then compared with the needs according to RDA.

\section{Objective criteria:}

Good $=$ if the intake of energy and protein in accordance with the needs according to RDA

Less $=$ if the intake of energy and protein less or one less than the needs according to RDA

6. Status of immunization in this study is the completeness of basic immunization toddlers are seen according to the records in the book child and mothers of healthy or KMS or notebook register at Posyandu according to age.

\section{Objective criteria:}

Yes complete $=$ if complete basic immunization in toddlers fit age Incomplete $=$ if imunisasai base in infants is incomplete His age appropriate 7. The statusfamily of 


\section{International Journal of Science and Research (IJSR) \\ ISSN (Online): 2319-7064 \\ Index Copernicus Value (2013): 6.14 | Impact Factor (2015): 6.391}

economic in this study is the description of the family's economic status toddler expressed by categories of income per capita. Per capita income is the total income earned huge family members in one month, then divided by the number of family members. Furthermore, per capita income data categorized by the edge of poverty from center of beureu statistic Papua Province

\section{Objective criteria:}

Low $=$ if the total per capita $\leq$ opinion from the edge of poverty according to Cnter of beureustatustic2014( $\leq \mathrm{Rp} .875,000)$

Height $=$ if the total income per capita $>$ of poverty threshold according to Center of beureu statistic 2014

(>Rp. 875,000)

8. Stunting in the study is the calculation of anthropometric body length or height for age (Length body / Age or High body /Age) were analyzed with an index value of Z-Score formula, the result is less than - $2 \mathrm{SD}$, that is shorter than the actual height. Stunted and severely stunted digolongkang into categories Stunting

Objective criteria:

Yes Stunting = if the value of the Z-Score index length /Age or Hight /Age of $<$ than - 22 SD Not Stunting $=$ if the value of the Z-Score index Length body /Age or Tall body/Age by $\geq-2$ SD

\section{Results and Discussion}

\section{A. Overview Location Research}

By Geographic location of the health center is located on the territory Senggi,Senggi District bordering the District of Waris is on the north, the south is the District Star Mountains, then District Towe and PNG to the east while the west is theJayapura District. PHC Senggiterletak in JalanMerpati in RT 01 / RW 01, City Senggi.The total area of approximately $3088.55 \mathrm{~km} 2$ Senggi District with at an altitude of 0-2000 meters above sea level and has a rainfall intensity is high enough territory. The whole village in District Senggi mostly located valley, as in the following table 6th:

Table 6th.Distribution ofthe villagein theworking areaof PHC Senggi, Keerom

\begin{tabular}{|c|c|c|c|c|}
\hline \multirow{2}{*}{ No } & \multirow{2}{*}{ Villlage } & \multicolumn{2}{|c|}{ Distance(km) } & \multirow{2}{*}{ Mileage } \\
\cline { 3 - 4 } & $\begin{array}{c}\text { Ofthe capital } \\
\text { district }\end{array}$ & $\begin{array}{c}\text { Fromthe district } \\
\text { capital }\end{array}$ & \\
\hline 1 & Senggi & 2 & 105 & 0,5 hours \\
\hline 2 & Warlef & 1 & 106 & 0,5 hours \\
\hline 3 & Woslay & 6 & 111 & 1,5 hours \\
\hline 4 & Usku & 30 & 135 & 7 hours \\
\hline 5 & Yabanda & 65 & 125 & 6 hours \\
\hline 6 & Molof & 24 & 129 & 6 hours \\
\hline
\end{tabular}

Source: PHCProfileSenggi, 2014
The total population in PHCSenggi as many as 3,588 people spread in six villages namely Senggi village town, village Warlef, Woslay village, Yabanda villageand Molofvillges. Population distribution more in Senggi quarter, Woslay and Molof villages. Two villages have the largest area among 4 other villages. Most of the total population is men as much as 2,037 people or $56.77 \%$ while the number of female population of 1,551 people or $43.22 \%$ of the total population. When compared with the total area which is an area of $3088.55 \mathrm{~km} 2$, the population density of 1 , this shows that for every area of $1 \mathrm{~km} 2$ is inhabited by more than one person. Patterns of life customs and lifestyle most people rely heavily on natural Senggi. This greatly affects the health status and community nutrition. For it is of great concern for health centers and in particular Senggi, Senggi District Government.

Most of the population Society Senggi livelihood as farmers and other professions such as gold panning working people, workers at some companies - companies that are operating in the District Senggi and some small work in education, health, and other governments. Dependence of a very large community of nature as a livelihood, making it difficult to achieve a society that is prosperous living standards, because there is no concept of production and community residents rely mostly worked with gardening very dependent on the weather and season.

PHC Senggi in conducting health services assisted by 4 pustu (Puskesmas) were divided in four villages namely: Woslay village, Usku village, town and village YabandaMolof. Three community health clinic is to provide health services to the community is only handled by a nurse and the only community health clinic villagesMolof that there is no health worker

\section{B. Results}

\section{Characteristics of Respondents}

Characteristics of respondents in this study include the age of mothers, education, employment and the number of members in the family. Respondents aged 17-year lows, the highest 39 years, then the age of the respondents were grouped into a young age $<20$ years and adult age is 20-40 years. Education mothers lows are not in school, the highest college (S-1), further education of respondents are grouped into low education $\leq \mathrm{SMP}$, the highest $>$ SMA, occupation highly variable ranging from housewives to civil servants, including teachers and private The next job are grouped into work and do not work, number of family members least 3 people and the number of family members most 7 , then the number of family members living in one house are grouped into a number of families little if $\leq 4$ and the number of families a lot of $>4$ people. For more details, characteristics of respondents can be seen in Table 7th below. 


\section{International Journal of Science and Research (IJSR) \\ ISSN (Online): 2319-7064}

Index Copernicus Value (2013): 6.14 | Impact Factor (2015): 6.391

Table7th.Distribution ofRespondents bycharacteristics(age, education, The amountof workandfamily members) in theworking areaPHCSenggi, Keerom2015

\begin{tabular}{|c|c|c|c|c|c|c|c|}
\hline \multirow{2}{*}{ No } & \multirow{2}{*}{ Carakteristic } & \multicolumn{2}{|c|}{ Control } & \multicolumn{2}{|c|}{ Cases } & \multirow[t]{2}{*}{$\mathrm{n}$} & \multirow[t]{2}{*}{$\%$} \\
\hline & & $\mathrm{n}$ & $\%$ & $\mathrm{n}$ & $\%$ & & \\
\hline 1 & $\begin{array}{l}\text { AgeMotherToddlers } \\
\text { a.Young(<20years) } \\
\text { b.Dewasa(20-40 Years) }\end{array}$ & $\begin{array}{l}17 \\
47\end{array}$ & $\begin{array}{l}26.6 \\
73.4\end{array}$ & $\begin{array}{c}0 \\
32\end{array}$ & $\begin{array}{c}0 \\
100\end{array}$ & $\begin{array}{l}17 \\
79 \\
\end{array}$ & $\begin{array}{l}17.7 \\
82.3\end{array}$ \\
\hline & Amount & 64 & 100 & 32 & 100 & 96 & 100 \\
\hline 2 & $\begin{array}{ll}\text { Mothereducationtoddler } & \\
\text { a.High }(>\text { SeniorHigh } & \text { School }) \\
\text { b. Low }(\leq \text { Junior high school }) & \end{array}$ & $\begin{array}{l}20 \\
44 \\
\end{array}$ & $\begin{array}{l}31.3 \\
68.8\end{array}$ & $\begin{array}{l}17 \\
15\end{array}$ & $\begin{array}{l}53.1 \\
46.9\end{array}$ & $\begin{array}{l}37 \\
59 \\
\end{array}$ & $\begin{array}{l}38.5 \\
61.5\end{array}$ \\
\hline & Amount & 64 & 100 & 32 & 100 & 96 & 100 \\
\hline 3 & $\begin{array}{l}\text { Work } \\
\text { a.Does not work } \\
\text { b. a work }\end{array}$ & $\begin{array}{l}52 \\
12 \\
\end{array}$ & $\begin{array}{l}81.3 \\
18.8 \\
\end{array}$ & $\begin{array}{c}29 \\
3\end{array}$ & $\begin{array}{c}90.6 \\
9.4\end{array}$ & $\begin{array}{l}81 \\
15\end{array}$ & $\begin{array}{l}84.4 \\
15.6\end{array}$ \\
\hline & Amount & 64 & 100 & 32 & 100 & 96 & 100 \\
\hline 4 & $\begin{array}{l}\text { Number offamilymembers } \\
\text { a.a.existBit }(\leq 4) \\
\text { b. a Many }(>4)\end{array}$ & $\begin{array}{l}45 \\
19 \\
\end{array}$ & $\begin{array}{l}70.3 \\
29.7 \\
\end{array}$ & $\begin{array}{l}13 \\
19 \\
\end{array}$ & $\begin{array}{l}40.6 \\
59.4 \\
\end{array}$ & $\begin{array}{l}58 \\
38 \\
\end{array}$ & $\begin{array}{l}60.4 \\
39.6 \\
\end{array}$ \\
\hline & Amount & 64 & 100 & 32 & 100 & 96 & 100 \\
\hline
\end{tabular}

\section{Source: Primary Data processed}

From thetable.7above shows that the younger the respondents were aged $26.6 \%$ of the control group and $100 \%$ of the adult age group of cases. High responder education as much as $53.1 \%$ of cases and $68.8 \%$ of education lower than the control group. Occupation of respondents did notwork $90.6 \%$ of the case group and the control groupby $81.3 \%$. While the number of family members slightly $70.3 \%$ of the control group and the number of family members lots of $59.4 \%$ of the cases.

\section{Characteristics Sample}

Characteristics ofthe samplesuch as ageand genderin the control groupandthe case group.Characteristics of the sample according to the lowest age of 12 months and 59 months of age the highest sample. While the gender of samples between genders male and female sex almost equal between the case group and the control group. More detail can be seen in Table 8th below.

Table 8th. Distribution of Samples by Age and Gender on The case group and the control group in the working area Senggi health center, Keerom 2015

\begin{tabular}{|c|c|c|c|c|c|c|c|}
\hline \multirow{2}{*}{ No } & \multirow{2}{*}{ Variable } & \multicolumn{2}{|c|}{ Control } & \multicolumn{2}{|c|}{ Cases } & \multirow[t]{2}{*}{$\mathrm{n}$} & \multirow[t]{2}{*}{$\%$} \\
\hline & & $\mathrm{n}$ & $\%$ & $\mathrm{n}$ & $\%$ & & \\
\hline 1 & $\begin{array}{l}\text { AgeToddlers } \\
\text { a.Under twoyears(12-23Months) } \\
\text { b.Toddlers(24-59 months) }\end{array}$ & $\begin{array}{l}32 \\
32\end{array}$ & $\begin{array}{l}50.0 \\
50.0\end{array}$ & $\begin{array}{l}13 \\
19\end{array}$ & $\begin{array}{l}40.6 \\
59.4\end{array}$ & $\begin{array}{l}45 \\
51\end{array}$ & $\begin{array}{l}46.9 \\
53.1\end{array}$ \\
\hline & Amount & 64 & 100 & 32 & 100 & 96 & 100 \\
\hline 2 & $\begin{array}{l}\text { Gendertoddler } \\
\text { a.Man } \\
\text { b. female }\end{array}$ & $\begin{array}{l}32 \\
32 \\
\end{array}$ & $\begin{array}{l}50.0 \\
50.0 \\
\end{array}$ & $\begin{array}{l}16 \\
16 \\
\end{array}$ & $\begin{array}{l}50.0 \\
50.0 \\
\end{array}$ & $\begin{array}{l}48 \\
48 \\
\end{array}$ & $\begin{array}{l}50.0 \\
50.0 \\
\end{array}$ \\
\hline & Amount & 64 & 100 & 32 & 100 & 96 & 100 \\
\hline
\end{tabular}

\section{Source: Primary Data processed}

Based on the table above shows that the age group 24-59 years in the case of larger compared with age $<24$ months which is $59.4 \%$, whereas in the control group between age $<24$ months and $\geq 24$ months, respectively 50\%. Similarly, sex between men and women both in the case group and the control group each as large as 50\% male and 50\% female.

\section{Univariate Analysis.}

\section{a. Historical overview Eating Mothers During} Pregnancy, History of exclusivebreastfeeding, complementary feeding Giving history, history of infections diseases

Overview history of eating mothers during pregnancy, exclusive breastfeeding history, history of gift weaning food, a history of infectious diseases, immunization status of children, and family economic status. History of eating the mother during pregnancy both in the case group and the control group was very varied as during pregnancy toddler stunting anyone has complaints of nausea, causing the mother does not like to eat food, even up to the gestational age almost 6 months, but some say Mediocre no complaints. History is not all exclusive breastfeeding mother toddler breastfeeding in infants exclusively. Mother breastfeeding since baby till 2 month lows only reason the child does not want to breastfeed, there are states Asi did not come out. Similarly, the history of gift weaning found no mothers who give breast milk too early with his reasons do not want to drink the milk again so that their children are not fussy then given porridge. While the gift weaning highest youngest 1 month 6 months, for the reason that milk is lacking and there are states hungry children continues. Type complemnetary of feeding given as porridge empty and if money can buy pulp purchased in a small shop or store in Keerom. In fact, there are mothers who deliver children were given rice mashed with vegetable broth just to be given a drink of water or sometimes milk.

\section{Volume 5 Issue 7, July 2016 www.ijsr.net}




\section{International Journal of Science and Research (IJSR) \\ ISSN (Online): 2319-7064 \\ Index Copernicus Value (2013): 6.14 | Impact Factor (2015): 6.391}

Then for the immunization status of children under five were found to be still incomplete immunization of children due to her warm as cold and cough some say fever. There is also a mother who went to the village and or gardening and others. Family economic status was found to be very alarming because the husband does not work, so mothers should be gardening or farming and selling vegetables. For details as in table 9 th below.

Table 9th.Samples Distribution Based on the history of the mother ate during pregnancy, Exclusive breastfeeding history, history of Complementary feeding, history Infectious diseases, in PHCSenggi, Keerom, 2015

\begin{tabular}{|c|c|c|c|c|c|c|c|}
\hline \multirow{2}{*}{ No } & \multirow{2}{*}{ Variable } & \multicolumn{2}{|c|}{ Control } & \multicolumn{2}{|c|}{ Cases } & \multirow[t]{2}{*}{$\mathrm{n}$} & \multirow[t]{2}{*}{$\%$} \\
\hline & & $\mathrm{n}$ & $\%$ & $\mathrm{n}$ & $\%$ & & \\
\hline 1 & $\begin{array}{l}\text { History Eating Mothers During Pregnancy } \\
\text { a.Good } \\
\text { b. Less }\end{array}$ & $\begin{array}{l}40 \\
24\end{array}$ & $\begin{array}{l}62.5 \\
37.5\end{array}$ & $\begin{array}{l}11 \\
21\end{array}$ & $\begin{array}{l}34.4 \\
65.6\end{array}$ & $\begin{array}{l}51 \\
45\end{array}$ & $\begin{array}{l}53.1 \\
46.9\end{array}$ \\
\hline & Amount & 64 & 100 & 32 & 100 & 96 & 100 \\
\hline 2 & $\begin{array}{l}\text { Exclusive breastfeeding history } \\
\text { a.Yes } \\
\text { b. No }\end{array}$ & $\begin{array}{l}12 \\
52\end{array}$ & $\begin{array}{l}18.8 \\
81.3\end{array}$ & $\begin{array}{l}22 \\
10\end{array}$ & $\begin{array}{l}68.8 \\
31.3\end{array}$ & $\begin{array}{l}34 \\
62\end{array}$ & $\begin{array}{l}35.4 \\
64.6\end{array}$ \\
\hline & Amount & 64 & 100 & 32 & 100 & 96 & 100 \\
\hline 3 & $\begin{array}{l}\text { Giving history complementary feeding } \\
\text { a.Yes } \\
\text { b. No }\end{array}$ & $\begin{array}{l}49 \\
15\end{array}$ & $\begin{array}{l}76.6 \\
23.4\end{array}$ & $\begin{array}{l}12 \\
20\end{array}$ & $\begin{array}{l}37.5 \\
62.5\end{array}$ & $\begin{array}{l}64 \\
35\end{array}$ & $\begin{array}{l}63.5 \\
36.5\end{array}$ \\
\hline & Amount & 64 & 100 & 32 & 100 & 96 & 100 \\
\hline 4 & $\begin{array}{l}\text { HistoryInfectious Diseases } \\
\text { a.No } \\
\text { b. Yes }\end{array}$ & $\begin{array}{l}38 \\
26\end{array}$ & $\begin{array}{l}59.4 \\
40.6\end{array}$ & $\begin{array}{c}8 \\
24\end{array}$ & $\begin{array}{l}25.0 \\
75.0\end{array}$ & $\begin{array}{l}46 \\
50\end{array}$ & $\begin{array}{l}47.9 \\
52.1\end{array}$ \\
\hline & Amount & 64 & 100 & 32 & 100 & 96 & 100 \\
\hline
\end{tabular}

\section{Source: Primary Data processed}

Table 9 shows that the history of the mother ate during pregnancy in both the control group by $62.5 \%$ compared with the cases, whereas history when pregnant women eat less in the case of a larger group than the control group in the amount of $46.9 \%$. For a history of exclusive breastfeeding in infants in the case group, (yes to give) of $68.8 \%$, while those not breastfed exclusively in the control group larger than the case in the amount of $81.3 \%$. Then in the history of Mother's gift weaning in infants, $76.6 \%$ in the control group, while women who did not give breast milk to infants in the group there are $62.5 \%$ of cases. In the history of infectious diseases $75 \%$ in the case group, $59.4 \%$ no history of infectious diseases found in the control group.

\section{b. Nutritional Intake picture, Immunization Status and Family Economic Status}

Nutritional intake include the intake of energy and nutrients protein, energy intake low of $556.7 \mathrm{kcal}$, the highest 1980.3 kcal whereas protein intake lows 12.9 grams, the highest 30.7 gram as compared to the needs based on the number the recommended dietary allowance, it can be seen $\%$ intake of energy and protein further grouped into either intake or less. Similarly, immunization status can be determined completeness of immunization records in the card to healthy / health of both mother and child book children under age appropriate children who should, then grouped into complete or incomplete. For economic status is obtained based on income recognition mother and her husband or other family members who live in the same house and eat one kitchen. Total income earned huge family members in one month, then divided by the number of family members. Furthermore, per capita income data categorized by the edge of poverty from BPS Papua province, then grouped into low and high income. More detail can be seen in Table 10th below.

Table10th. Distribution of Samples Based on Nutrient Intake and the Immnuization Status Family Economic Status in PHC Senggi, Keerom, 2015

\begin{tabular}{|c|c|c|c|c|c|c|c|}
\hline \multirow{2}{*}{ No } & \multirow{2}{*}{ Variable } & \multicolumn{2}{|c|}{ Control } & \multicolumn{2}{|c|}{ Cases } & \multirow[b]{2}{*}{$\mathbf{n}$} & \multirow{2}{*}{$\%$} \\
\hline & & $\mathrm{n}$ & $\%$ & $\mathrm{n}$ & $\%$ & & \\
\hline 1 & $\begin{array}{l}\text { Nutritionalintake } \\
\text { a.Good }\end{array}$ & 30 & 46.9 & 10 & $\begin{array}{l}31.3 \\
687\end{array}$ & $\begin{array}{l}40 \\
56\end{array}$ & $\begin{array}{l}41.7 \\
58.2\end{array}$ \\
\hline & b. Less & 34 & 53.1 & 22 & 68.7 & 56 & 58.3 \\
\hline & Amount & 64 & 100 & 32 & 100 & 94 & 100 \\
\hline 2 & $\begin{array}{l}\text { Immunization Status } \\
\text { a. Complete } \\
\text { b. Incomplete }\end{array}$ & $\begin{array}{l}45 \\
19\end{array}$ & $\begin{array}{l}70.3 \\
29.7\end{array}$ & $\begin{array}{l}13 \\
19\end{array}$ & $\begin{array}{l}40.6 \\
50.4\end{array}$ & $\begin{array}{l}58 \\
38\end{array}$ & $\begin{array}{l}60.4 \\
39.6\end{array}$ \\
\hline & Amount & 64 & 100 & 32 & 100 & 96 & 100 \\
\hline 3 & $\begin{array}{l}\text { FamilyEconomicStatus } \\
\text { a.High } \\
\text { b. Low }\end{array}$ & $\begin{array}{l}40 \\
24\end{array}$ & $\begin{array}{l}62.5 \\
37.5\end{array}$ & $\begin{array}{l}18 \\
14\end{array}$ & $\begin{array}{l}43.7 \\
56.3\end{array}$ & $\begin{array}{l}58 \\
38\end{array}$ & $\begin{array}{l}60.4 \\
39.6\end{array}$ \\
\hline & Amount & 64 & 100 & 32 & 100 & 96 & 100 \\
\hline
\end{tabular}

Source: Primary Data processed 


\section{International Journal of Science and Research (IJSR) \\ ISSN (Online): 2319-7064 \\ Index Copernicus Value (2013): 6.14 | Impact Factor (2015): 6.391}

Table 10 shows the intake of nutrients (energy and protein) by $68.8 \%$ less present in children under five cases and $46.9 \%$ good nutritional intake in the control group. Completed immunization status of $70.3 \%$ found in the control group and $50.4 \%$ contained incomplete in the case group. Economic status are lower by $43.8 \%$ in the case group and $62.5 \%$ of high economic status contained in the control group.

\section{c. Overview of events Stunting in Childhood}

Stunting picture toddler screening result nutritional status through anthropometric measurements body length and height of children under five. Furthermore, the measurement results were analyzed using WHO Anthro 2005 program and anthropometric indices High /Age or Lenght / Age. Lowest $65.2 \mathrm{~cm}$ high, $116.9 \mathrm{~cm}$, high with a median of $90.03 \mathrm{~cm}$. Having analyzed using Index Z Score High /Age or Lenght / Age lowest values obtained Zsore-1.273928 Median 3.636364 highest with 2.4. Based on these results it can be seen stunting and no stunting. Details can be seen in the following table. 11 th be low
Table 11th.Samples DistributionBasedStuntingInPublic health center Senggi,Keerom, 2015

\begin{tabular}{|l|l|l|l|}
\hline No & Stunting & $\mathrm{n}$ & $\%$ \\
\hline a. & Yes & 32 & 33.3 \\
b. & No & 64 & 66.7 \\
\hline & Amount & 96 & 100 \\
\hline
\end{tabular}

\section{Source: Primary Data processed}

Based on the above table shows that $33.3 \%$ of the sample had nutritional status of stunting and $66.7 \%$ no stunting. Stunting state and stunting in children under five are scattered in 4 villages (Senggi, Wosley,Werlef and Yabanda)

\section{Analysis Bevariate \\ a. Exclusive Breastfeeding Relationship History With Incidence of Stunting}

The relationship betweenexclusive breastfeeding history with events Stunting among children aged 1-5 years in Public Health Center Senggi, Keerom district, on the terms ofsuchresearch resultsin Table12thbelow.

Table 12th. Exclusive Breastfeeding Relationship History with Incidence of Stunting in Childhood In Public health center Senggi, Keerom 2015

\begin{tabular}{|c|c|c|c|c|c|c|c|c|c|}
\hline \multirow{2}{*}{ No } & \multirow{2}{*}{$\begin{array}{l}\text { Eating History when mothers } \\
\text { Pregnant }\end{array}$} & \multicolumn{2}{|c|}{ Control } & \multicolumn{2}{|c|}{ Cases } & \multirow{2}{*}{ P. value } & \multirow[b]{2}{*}{ OR } & \multicolumn{2}{|c|}{ CI $95 \%$} \\
\hline & & $\mathrm{n}$ & $\%$ & $\mathrm{n}$ & $\%$ & & & $\mathrm{~L}$ & $\mathrm{U}$ \\
\hline 1 & Good & 40 & 62.5 & 11 & 34.4 & \multirow{3}{*}{0.00} & \multirow{3}{*}{$<1$} & \multirow{3}{*}{0.040} & \multirow{3}{*}{0.278} \\
\hline 2 & Less & 24 & 37.5 & 21 & 65.6 & & & & \\
\hline & Amount & 64 & 100 & 32 & 100 & & & & \\
\hline
\end{tabular}

Source: Primary Data processed

Table 12 shows that the control group had a history of eating the mother during pregnancy, both at $62.5 \%$. Whereas in the case of groups that have a history of the mother during pregnancy eat less by $65.6 \%$. Based on statistical test showed a $\mathrm{P}$ value of $0.00(\mathrm{P}<0.05)$, then there is a history of relationship with the incidence of exclusive breastfeeding Stunting in children under five in the region Public Health Center Senggi. Value Odds Ratio showed $<1$, then the history of the mother ate during pregnancy is protetic for the occurrence of stunting, meaning the history of the mother during pregnancy eat well, small to risk the incidence of stunting, compared with the history of the mother during pregnancy eat less.

\section{b. The realtionship Of Giving history a weaning With Genesis Stunting in Toddlers at Public helath centerSenggi, Keerom}

The relationship of gift weaning and the incidence of stunting as in table 13 th

Table 13th. Relationship History Grant Complementary feeding In Genesis Stunting on Toddler In Region Health Senggi, Keerom, 2015

\begin{tabular}{|c|c|c|c|c|c|c|c|c|}
\hline Provisionof & \multicolumn{2}{|c|}{ Control } & Cases & \multirow{2}{*}{ P. } & & \multicolumn{2}{|c|}{ CI 95 \% } \\
$\begin{array}{c}\text { Complementary } \\
\text { feeding }\end{array}$ & $\mathrm{n}$ & $\%$ & $\mathrm{n}$ & $\%$ & value & OR & $\mathrm{L}$ & $\mathrm{U}$ \\
\hline Yes & 49 & 76.6 & 12 & 37.5 & & & & \\
\hline No & 15 & 23.4 & 20 & 62.5 & 0.00 & 5.444 & 2.169 & 13.664 \\
\hline Amount & 64 & 100 & 32 & 100 & & & & \\
\hline
\end{tabular}

Source: Primary Data processed.
Based on table 13, shows that in the case group had a history of not giving breast milk is not in accordance with the age of the child and not in accordance with the recommendation feeding amounted to $62.5 \%$ and in the control group had a history of gift weaning age-appropriate and recommended by feeding amounted to $76.6 \%$. Results of statistical test $\mathrm{P}$ value $=0.00(\mathrm{P}<0.05)$, meaning that there is a significant association between a history of gift weaning with events Stunting in children under five with $\mathrm{OR}=5,444$, meaning that history MP- Asi granting nonexclusive or not in accordance with advice and in accordance with the advice to eat has a 5 times greater risk for stunting occurs in infants compared with a history of gift weaning age-appropriate and as directed by a meal.

\section{c. The Relationship History of exclusive breastfeeding with Genesis Stunting}

Mother's Milk is the main food for infants to children aged at least two years. A baby at the age of 0-6 months daily for survival only fed breast milk alone by his mother when he was a toddler .Its on known breast milk alone for the breastfeeding (exclusive breastfeeding) in infants aged 0-6 months time is very important. Relationship history of exclusive breastfeeding in infants with an incidence of stunting in Senggi Public health center working area can be seen in the following table 14 th 


\section{International Journal of Science and Research (IJSR)}

ISSN (Online): 2319-7064

Index Copernicus Value (2013): 6.14 | Impact Factor (2015): 6.391

Table $14^{\text {th }}$ Relationship Giving History of exclusive breastfeedingwith Genesis Stunting in Toddlers In Public health center working area Senggi, Keerom, 2015

\begin{tabular}{|c|c|c|c|c|c|c|c|c|}
\hline \multirow{2}{*}{$\begin{array}{l}\text { The granting of exclusive } \\
\text { breastfeeding }\end{array}$} & \multicolumn{2}{|c|}{ Control } & \multicolumn{2}{|c|}{ Cases } & \multirow{2}{*}{$\begin{array}{c}P . \\
\text { value }\end{array}$} & \multirow{2}{*}{ OR } & \multicolumn{2}{|c|}{ CI $95 \%$} \\
\hline & $\mathrm{n}$ & $\%$ & $\mathrm{n}$ & $\%$ & & & $\mathrm{~L}$ & $\mathrm{U}$ \\
\hline Yes & 12 & 18.8 & 22 & 68.8 & & & & \\
\hline No & 52 & 81.3 & 10 & 31.3 & 0.00 & 0.105 & 0.040 & 0.270 \\
\hline Amount & 64 & 100 & 32 & 100 & & & & \\
\hline
\end{tabular}

Source: Primary data processed

From the table 14 above shows that in the control group had a history of exclusive breastfeeding in infants by $18.8 \%$ compared with the case of $68.8 \%$. Being in the case group showed no history of exclusive breastfeeding in infants by $31.3 \%$ less compared to the control group. This shows that the history of exclusive breastfeeding is not the sole cause of stunting. But based on results of statistical test showed a $P$ value of 0.00 (pvalue $<0,05$ ) means that there is a history of giving Asi relations exclusively with the incidence of stunting in children under five. And OR $<1$ means that children who have a history of exclusive breastfeeding are not at risk for stunting incidence of $<1$ time compared to children who have a history of not given breast milk exclusively. Thus the history of exclusive breastfeeding is protective for Stunting does not occur.

\section{d. Infectious Disease history relationship with Genesis Stunting}

Infectious diseases are a common health fun for childrens addition to adults. A child suffering from infectious diseases will suffer from gastrointestinal disorders and respiratory tract, so sometimes will disrupt food consumption, and in the end if this is the case for a long time, children have nutritional disorders. History relationship with the incidence of infectious diseases such as stunting in the following table 15th below.

Table 15th.RelationshipHistoryInfectious Diseases With Genesis Stunting in Toddlers In Puskesmas working area Senggi, Keerom

\begin{tabular}{|c|c|c|c|c|c|c|c|c|}
\hline HistoryInfectious & \multicolumn{2}{|c|}{ Control } & \multicolumn{2}{|c|}{ Cases } & \multirow{2}{*}{ Pvalue } & \multirow{2}{*}{ OR } & \multicolumn{2}{|c|}{ CI 95 \% } \\
\cline { 2 - 7 } Diseases & $\mathrm{n}$ & $\%$ & $\mathrm{n}$ & $\%$ & & & $\mathrm{~L}$ & $\mathrm{U}$ \\
\hline No & 38 & 59.4 & 6 & 25.0 & & & & \\
Yes & 26 & 40.6 & 24 & 75.0 & 0.003 & 4.385 & 1.708 & 11.257 \\
\hline Amount & 64 & 100 & 32 & 100 & & & & \\
\hline
\end{tabular}

Source: Primary data processed

Table 15th shows that the control group did not have a history of infections by $59.4 \%$, while in the case group had a history of infectious diseases at $75.0 \%$. From the statistical test $\mathrm{P}$ value of $0.003(\mathrm{P}<0.05)$, meaning that a history of infectious diseases in infants related significantly to the incidence of stunting. OR value for 4385 , this shows a history of infectious diseases in infants at risk for stunting incidence was 4 times greater than children who do not have a history of infectious diseases. Thus any infectious diseases suffered by children under five will cause growth disorders weight according to age.

\section{e. Nutritional Intake relationship with incidence of Stunting}

Nutritional intake is the input of nutrients in the daily diet diasup by toddlers. The better nutrition include energy and protein nutrients among children everyday is a factor that can affect the nutritional condition (Adriana M (2011). The relationship of nutrient intake with the incidence of stunting in children under five in Public health center Senggi like 16th in the table below.

\section{Table 16.Relationship Nutritional Intake With incident Stunting in Toddlers In the working area of Public Health CenterSenggi, Keerom, 2015}

\begin{tabular}{|c|c|c|c|c|c|c|c|c|}
\hline \multirow{2}{*}{$\begin{array}{l}\text { Nutritional } \\
\text { Intake }\end{array}$} & \multicolumn{2}{|c|}{ Control } & \multicolumn{2}{|c|}{ Cases } & \multirow{2}{*}{ Pvalue } & \multirow{2}{*}{ OR } & \multicolumn{2}{|c|}{ CI $95 \%$} \\
\hline & $\mathrm{n}$ & $\%$ & $\mathrm{n}$ & $\%$ & & & $\mathrm{~L}$ & $\mathrm{U}$ \\
\hline Good & 38 & 59.4 & 10 & 31.3 & \multirow{3}{*}{0.017} & \multirow{3}{*}{3.215} & \multirow{3}{*}{1.309} & \multirow{3}{*}{7.898} \\
\hline Less & 26 & 40.6 & 22 & 68.8 & & & & \\
\hline Amount & 64 & 100 & 32 & 100 & & & & \\
\hline
\end{tabular}

\section{Source: Primary data processed}

Based on the table 16 shows that the control group had a good nutritional intake amounted to $59.4 \%$, whereas in the case group had less nutritional intake amounted to $68.8 \%$. From the statistical test results obtained by the $\mathrm{P}$ value of $0.017(\mathrm{P}<0.05)$, meaning that there is a relationship toddler nutrition intake with the incidence of stunting. OR analysis results obtained 3,215, meaning that nutritional intake is less risky for the incidence of stunting is 3 times greater than the intake of good nutrition. Nutrition is needed for the growth of children is the energy and nutrient intake of protein in addition to the fulfillment of macro-nutrients such as carbohydrates and fats, besides micronutrients such as vitamins and minerals. All of these nutrients are needed for the growth and development that will ultimately be obtained children grow up with normal, healthy and smart.

\section{f. Immunization Status relationship with the incidence of stunting}

Primary immunization in children under five include BCG, DPT (I, II, III), Polio (I, II, II) and Measles given from children aged $<1$ year. Immunization as a base to prevent transmission of infectious diseases such as tuberculosis, pertussis (whooping cough), tetanus, polio and measles. Besides, there is another that immunization against hepatitis to prevent tertularnyanya hepatitis. The disease often strikes children under five also attacks in adults. Children who suffer from infectious diseases will lead to low intake of nutrients in the meal, so that eventually the child will experience growth disorders. Relations immunization with the incidence of stunting as shown in Table 17th 


\section{International Journal of Science and Research (IJSR)}

ISSN (Online): 2319-7064

Index Copernicus Value (2013): 6.14 | Impact Factor (2015): 6.391

Table 17th. Relationship Status Immunization with Genesis of Stunting in toddlers In PHCSenggi, Keerom, 2015

\begin{tabular}{|l|c|c|c|c|c|c|c|c|}
\hline \multirow{2}{*}{ Imnuzation Status } & \multicolumn{2}{|c|}{ Control } & \multicolumn{2}{|c|}{ Cases } & \multirow{2}{*}{ P. } & \multirow{2}{*}{ OR } & \multicolumn{2}{|c|}{ CI 95 \% } \\
\cline { 2 - 7 } & $\mathrm{n}$ & $\%$ & $\mathrm{n}$ & $\%$ & Value & & $\mathrm{L}$ & $\mathrm{U}$ \\
\hline Complete & 45 & 70.3 & 13 & 40.6 & & & & \\
Incomplete & 19 & 29.7 & 19 & 59.4 & 0.010 & 3.462 & 1.427 & 8.397 \\
\hline \multicolumn{1}{|c|}{ Amount } & 64 & 100 & 32 & 100 & & & & \\
\hline
\end{tabular}

Source: Primary data processed

The table 4.12, shows that in the control group had complete immunization status as much as $70.3 \%$, whereas in the case group had incomplete immunization status as much as $59.4 \%$. Based on the statistical test results obtained $\mathrm{P}$ value of $0.010(\mathrm{P}<0.05)$, meaning that there is a correlation with the incidence of stunting immunization status. Value OR 3462, meaning that toddlers who have incomplete immunization status at risk to suffer stunting by 3 times greater than the toddlers who have incomplete immunization status. Immunization is an act to prevent any infectious disease that can be prevented by immunization.
So with full immunization (BCG, DPT, Polio, measles to hepatitis) children can be spared by the infectious disease. Infectious diseases that attack in children will lead to low nutrition foods that cause less nutritional status and eventually the child will be experiencing interference future growth and development.

\section{g. Relationship Status Economic With Genesis of Stunting}

Table $18^{\text {th }}$.Relationship Economic Status WithGenesisStuntingin Toddlers in Public Health CenterSenggi, Keerom,

2015

\begin{tabular}{|c|c|c|c|c|c|c|c|c|}
\hline \multirow{2}{*}{ Economic Status } & \multicolumn{2}{|c|}{ Control } & \multicolumn{2}{|c|}{ Cases } & \multirow{2}{*}{$\begin{array}{c}\mathrm{P} . \\
\text { value }\end{array}$} & \multirow{2}{*}{ OR } & \multicolumn{2}{|c|}{ CI $95 \%$} \\
\hline & $\mathrm{n}$ & $\%$ & $\mathrm{n}$ & $\%$ & & & $\mathrm{~L}$ & $\mathrm{U}$ \\
\hline $\operatorname{High}(>\operatorname{Rp} .875 .000)$ & 34 & 53.1 & 8 & 25.0 & & & & \\
\hline $\operatorname{Low}(\leq \operatorname{Rp} .875 .000)$ & 30 & 46.9 & 24 & 75.0 & 0.016 & 3.400 & 1.330 & 8.693 \\
\hline Jumlah & 64 & 100 & 32 & 100 & & & & \\
\hline
\end{tabular}

\section{Source: Primary data processed}

Table 18th, shows that in the control group had complete immunization status as much as $70.3 \%$, whereas in the case group had incomplete immunization status as much as $59.4 \%$. Based on the statistical test results obtained $\mathrm{P}$ value of $0.010(\mathrm{P}<0.05)$, meaning that there is a correlation with the incidence of stunting immunization status. Value OR 3462, meaning that toddlers who have incomplete immunization status at risk to suffer stunting by 3 times greater than the toddlers who have incomplete immunization status. Immunization is an act to prevent any infectious disease that can be prevented by immunization. So with full immunization (BCG, DPT, Polio, measles to hepatitis) children can be spared by the infectious disease. Infectious diseases that attack in children will lead to low nutrition foods that cause less nutritional status and eventually the child will be experiencing interference future growth and development

\section{Discussion Study}

1.Brief History Eat While Pregnant Mom, History Exclusive breastfeeding, complementary feeding Giving History, History Infensi Diseases, Nutritional Intake of Children toddlers, history Immunization Status, Family Economic Status, Stunting on Children

Results of research on risk factors for stunting prevalence in PuskesmasSenggi showed that risk factors for stunting was found on characteristics of respondents aged adults. Low education respondents have no stunting of children more than the highly educated. This shows that the condition of the adult age, low education and higher education and work as a housewife with children stunting. These results are consistent withresearch that finds Strong stunting in children under five years of age there are more women that adult education from primary to higher education.

Research in Bangladesh also found that the value of z-score of height for age, is better in children with highly educated mothers compared with less educated mothers. Parent education does not become a risk factor stunting due to many factors, which in this study are not all visible factors such as upbringing, the intake. Parental education has a direct impact on parenting which in turn affects food intake of children. Research in Bogor in 2005 mentioned that the education of parents directly influence parenting, which is not good parenting will cause the intake obtained child becomes unfavorable, resulting in the child grows stunting. In this research, the toddler stunting of over $30 \%$, a child stunting has been formed in the womb that is, from start time of conception until ready to be born. According to the SUN, in 2013, to get a baby born normal conditions, then adolescence to dinyakan in a state of pregnancy, monitoring of health and nutrition for the mother has to be considered. Monitoring the health of the mother is away from infectious and parasitic diseases, nutritional monitoring is the unmet need for nutrients in the daily diet even if conditions who are pregnant always impaired sicness morning or emesis due to the body can not take hormonal changes. In such conditions the fulfillment of nutrition in the diet remains to be fulfilled.

\section{Risk Factors Genesis Stunting On Childhood}

\section{a) Relationship History meal when Pregnant Mother With Stunting}

Incident results showed that in the control group mothers have a history of eating well during pregnancy and $62.5 \%$ in the case group had a history of eating the mother while pregnant were less. And there is a history of the relationship

\section{Volume 5 Issue 7, July 2016}

\section{www.ijsr.net}




\section{International Journal of Science and Research (IJSR) \\ ISSN (Online): 2319-7064 \\ Index Copernicus Value (2013): 6.14 | Impact Factor (2015): 6.391}

mother ate during pregnancy with the incidence of stunting in children under five. According Alamtsier (2001) fulfillment of energy and other nutrients during pregnancy is necessary for maternal health and fetal development, so that one day will grow in a healthy fetus. Thus the contribution of energy and nutrients in the daily diet - a day for a mother during pregnancy according to the needs, the growth and development of the fetus in the womb would normally manifested in body weight and body length were also normal birth. Adriana M, et al (2012) infants born with a body length shorter higher chance to grow shorter length than the children of normal birth weight. Children who grow up with a body length or height less proportionately with age showed that the child is in short condition. Short children showed no relationship due to lack of nutrition diasup by the mother during pregnancy, so it is not optimal fetal growth which resulted in the slow lorises born babies have low birth body length. Baranca, (2006) stated that part of the lives of several individuals starting from the time of conception were passed on from one generation to another. Furthermore, maternal nutrition during pregnancy as a determinant of the quality of human resources, the jea, evidence that the mother's nutrition and health conditions of the masses prenatal, when natal and while breastfeeding is a critical developmental period (MoH RI, 2013)

\section{b) Relationship History Exclusive breastfeeding Genesis Stunting}

UNICEF, (1990) states that the factors that are not directly related to the incidence of stunting among children under five are food availability and patterns of exclusive breastfeeding and complementary feeding in addition to the provision of health services, including immunization status.

Children who are given only breast milk during the first six months will experience good growth of the body. Because with breastfeeding can protect children from infectious diseases, it is due to that found in breast milk contains antibodies, protein and vitamin A. So that mothers who breastfeeding of infants up to the age of at least two years, will be very beneficial to the health of another for children's health also for the health of the mother.

The results showed that there was a history of exclusive breastfeeding relationship with the incidence of Stunting ( $\mathrm{P}$ $<0.05$ ). But the value of $\mathrm{OR}<1$, which means that exclusive breastfeeding is protective for the occurrence of stunting. The results of this study are supported by research Hien\&Kam, (2008), and Oktavia (2011), showed that the risk of being stunted by 3.7 times greater in infants who are not breastfed exclusively. Behavior mothers breastfed exclusively on child has a significant relationship with the occurrence stunted.

\section{c) Giving History breastfeeding Food Companion relationship with Genesis Stunting}

Kurniasih, et al (2010) stated that complementary foods are a food and drink other than breast milk given to infants after 6 months because of the need in granting the food companion of breasfeeding done gradually by using foodstuffs diverse, have variations, nutritious and made himself by her mother at home as well as complementary foods are ready to eat and given according to age. This is due to the baby's nutritional needs of growing old, it will be increased, so that breastfeeding alone is not sufficient.

Mother feeding behavior include behavioral health and nutrition (diet) during pregnancy, natal and postkelahiran for the mother and the toddler. A diet of infants and toddlers include breastfeeding and solid food (giving complementary of breastfeeding) more appropriate age. Feeding behavior is the way the mother in provide food and drink for children that aims to get enough nutrients needed for growth and development (Khomsan A 2005 in Mahlia Y, 2009).

Risk factors stunting due to risk factors that affect stunting aplenty and even in this study was found as a history of eating during pregnancy, a history of exclusive breastfeeding, history of giving the food companion of breastfeeding, a history of infectious diseases nutrition (energy and protein) and the immunization status in touch the incidence of stunting in children under five each value $(P$ $<0.05$ ) with OR value of more than 1 . This means that these factors are less at risk for the occurrence of stunting is greater than the good. Maternal food intake during pregnancy is foundation for growth and development of the fetus in the womb. With diverse dining while pregnant will contribute nutrients needed by both the mother and fetus.

$\mathrm{MOH}$, (2002) states that nutritional balance is obtained when the everyday dish consists of three groups of foodstuffs at the same time.Staple foods, side dishes, vegetables. And in the entree menu consists of at least two types of foodstuffs. This is the first message in the general guidelines as suggestions that balanced nutrition is important to do.

Several previous studies to support the results of this study are Wuryanto E. EnyWinaryati get mothers continued breastfeeding and milk $78.5 \%$, and the knowledge in breastfeeding up to 2 years of $41.5 \%$ has a chance to grow normally.

UNICEF, (2012) suggested that the process of becoming a child's short stature called the failure of growth (grow th faltering) begins in the womb, until the age of two years. By the time a child enters the age of 2 years is too late to repair damaged in the early years. Therefore, the health and nutritional status of the mother is an important determinant of short or tall body in children.

The results of the study Mahlia Y, (2009) that parenting a toddler eating according to the types of foods that do not complete their growth is not normally and there is a significant relationship between the provision of the type of food that is complete with growing children. And the frequency of children eating less well, having abnormal growth is greater than the frequency of eating well.

Thus it can be assumed that a toddler stunting caused by the behaviour of mothers who lack parenting which includes maternal care from the time of acquisition is less but a prenatal maternal knowledge is lacking, postnatal behaviour is still not well supported parenting milk motheri giving up 


\section{International Journal of Science and Research (IJSR) \\ ISSN (Online): 2319-7064}

Index Copernicus Value (2013): 6.14 | Impact Factor (2015): 6.391

feeding is still lacking. Lack of parenting behaviors have occurred relatively long, causing nutritional disorder (short)

Factors infectious disease also plays a parenting in determining whether the child will grow normally or stunting during his lifetime or catch-up reached the maximum grow. Short children are more at risk to grow more slowly so as to show the condition of stunting. Factors history of exclusive breastfeeding and complementary feeding contribute in a period of rapid growth of the child. Because in breast milk has nutrients a baby needs up to the age of 2 years, which further plus the nutrition gained in granting the complemtary of breast feeding quality and in accordance with the recommendation, it would be normal body growth with increasing age of the child.

The results are consistent with studies of Al-Rahmat, AmperaMiko and Abdul H, (2010) that the proportion of children under five are stunted, $58.3 \%$ due to the provision of complementary feeding poorly and breast feeding is not exclusive

\section{d) Relationship History Infectious diseases with Incidence of Stunting}

Infectious diseases are a direct cause of the occurrence of stunting in children under five (UNICEF, 1990). According to Damanik, et al, (2010) that is a manifestation of infectious diseases caused by nutritional disorders in addition to insufficient $\backslash$ uyang nutrients absorbed from food diasup also the amount of nutrients needed by the body is not appropriate. This problem occurs as a manifestation of the consequences of inadequate nutrition of the food or as a result of a variety of infectious diseases suffered causing increased energy and nutrient needs and decreased appetite due to illness or the effects of disturbance absorption in the intestine.

Maxwell, (2011) states that malnutrition and infectious disease that affects the often occur simultaneously, nutritional disorders can increase the risk of infectious disease, diseases infkeakan opposite effect on the occurrence of nutritional disorders.

The results of this study found no correlation with the incidence of infectious disease history stunting in infants $(\mathrm{P}$ $<0.05)$ with $\mathrm{OR}=4,385$, meaning that the incidence of infectious disease are at risk of stunting more 4 times compared with patients with no history of infectious disease.

The results are consistent with research interest $\mathrm{RCH}$. Rossa, et al (2012) found no association with the occurrence of infectious diseases stunting.

\section{e) Relationship with Genesis Stunting Immunization Status}

Immunization in children balitan meaningful to the incidence of stunting in children under five. Immunization in infants stated that the provision of basic immunization that includes vaccine in infants: from hepatitis $\mathrm{B}, \mathrm{BCG}$, Polio, DPT and measles aims to prevent toddlers to avoid contracting infectious diseases. Infants and children who suffer from pain or infection will experience an eating disorder input over time the body will lack the nutrients. To prevent children from falling ill, the mother will do a complete basic immunization in children under five. Complete basic immunization to prevent infectious diseases such as tuberculosis, measles, whooping cough, diphtheria and hepatitis (MOH, 2013).

Immunization status in children is one indicator of contact with kesehayan services, because their contact with health services will helped in improving the nutritional problems of recent disturbance. According Yimer, (2000) that with complete immunization status will be able to make a positive impact on the nutritional status of children under five in the long term.

The results showed that there is a correlation with the incidence of stunting immunization status $(\mathrm{P}<0.05)$ with $\mathrm{OR}$ 3.462.bahwa incomplete immunization status untjuk briefly unsettled the market risk of stunting in children under five. The results of the study are in line with some of the results of research that studies Neldawati, (2006) that the immunization status have a meaningful relationship with index of the nutritional status of hight / age in children. Thus it is the result of research Milman, et.all, (2005) showed that the immunization status becomes Underlying factor in the incidence of stunting in children under five. Taguri research, et.all (2007) also found incomplete immunization status associated with the incidence of stunting in children under five.

The study's findings also supported by research Aswin, Saryonoand DianRamawati, (2007), which received that granting full immunization $72.5 \%$ and no correlation with nutritional status. The results of the study Wiyogowati C., (2012) with the title of Genesis Stunting in children under five years of age (0-59 months) in the province of West Papua (Data Analysis Riskesdas 2010), getting there is a relationship between the basic immunization with Stunting events.

Complete basic immunization in children is a mother how to maintain their health in order not to sick children by providing immunizations as recommended by the government adjusted according to the age group of infants. By providing basic immunization will provide immunity to the disease effects needed by infants to toddlers, child impact seringb disease are suffering from malnutrition or poor nutrition (MOH RI, 2007). Supariassa, et al, (2002) states that children receive immunizations will be healthy is not easy to catch an infectious disease that ultimately are not malnourished.

\section{f. Nutritional Intake Relationship with Stunting events}

The factors associated with the occurrence of stunting according to UNICEF, (1990) among children directly is not balanced nutrition and infectious diseases suffered. The results showed in the cases of malnutrition intake amounted to $68.7 \%$ and the control group a good nutritional intake of $46.9 \%$. And there is a relationship of nutrient intake with the incidence of stunting $(\mathrm{P}<0.05)$ with $\mathrm{OR}=3,215$, it means

\section{Volume 5 Issue 7, July 2016 www.ijsr.net}




\section{International Journal of Science and Research (IJSR) \\ ISSN (Online): 2319-7064}

Index Copernicus Value (2013): 6.14 | Impact Factor (2015): 6.391

that the nutritional intake have less risk of stunting 3 times greater than the intake of good nutrition.

According to Arora, (2009) good nutrition and balanced an important part of quality of life. This concurs with et.allRamli (2009) that the adequate nutrition needed to ensure optimal growth and development for infants and children. Nutrients needed between toddlers with each other toddlers his age differently according denganm. These nutrients include protein, fat, carbohydrates, vitamins and minerals contained in food a day - the day that it consumes adequacy of nutrient intake of total energy, protein, fat and carbohydrates and micronutrients, will relate to the physical growth deficit child (ACC / SCN, 2000).

The results of this study found that the nutritional intake of children under five are risk factors for stunting. Nutritious feeding in children after birth is liable tangguang mothers or parents in parenting feeding enough energy and other nutrients. In this study, the results show that there is a relationship of nutrient intake with the incidence of stunting in children under five $(\mathrm{P}<0.05)$ with $\mathrm{OR}>1$. Mothers parenting behaviour means the practice of mothers in educating, guiding, nurturing and taking care of children. Mother in parenting begins child in the womb, after birth until the age of five that includes the supply and provide meals, drinks, a following clothing, take care hygiene of children and the home environment, preserve and maintain the health of children and everything that ibuthkan child (Rapar VL, et al, 2014).

This study is in line with research conducted in Semarang in 2011 showed that parenting Ms. Low is a risk factor stunting in children aged 24-36 months. Research in Bangladesh also shows that many children stunting in women who have a habit of people in giving food less nutritious risk factors stuntingorang old is now a genetic influence or the influence pathologic or malnutrition. Thus parents who were less attention to food and beverages to children after birth until the age of five, it will face the problem of nutrition as well as pathological, in children.

\section{g. Economic Relationship Status With Genesis Stunting}

In this study also found no correlation with the incidence of family economic status of stunting in children under five $(\mathrm{P}$ $<0.05)$ and OR $>1$. According to Unicef (1990) that the root causes of malnutrition as a result of the problems of the poor economy conditions. Indirectly low family economy will affect the family in providing food for the family members including the quality of food provided. Adequacy eat very berganung on the ability to buy groceries and supported by knowledge in selecting groceries purchased until how to process these foods into a diet rich in nutrients are also required for the toddler.

Wirjadmadi, B, (2011) states that low family economic status will affect the quality or quantity of food consumed by the family. Food gained will usually be less variable and fewer in number, especially in food for growing children which serves as a source of protein, vitamins and minerals, thus increasing the risk of malnutrition. This limitation will increase the risk of stunting in children under five, the study in children aged 2-3 years in Semarang in 2012 stated that low economic status associated with the limitations of the family in meeting the need for nutrients both macro and micro nutrients.

The roots of the problem of malnutrition (stunting, underweight and wasting) is poverty. In addition to poverty there are other factors that can affect stunting in children. The incidence of stunting affected by residential areas.Research shanty town in the region conducted by MahgoupBostwana.shows that children living in the region is significantly affected by wasting, stunting and underweight (Flower ChRosha, Hardinsyah and Yayuk Farida Baliwati, 2012).

\section{Conclusions and Recommendations}

\section{A. Conclusion Based on the results and discussion, it can be concluded as follows:}

1) History mothers eat during pregnancy in case group is less by $65.6 \%$ and in the control group had a history of eating well during pregnancy mothers $62.5 \%$. History of breastfeeding in the case of non-exclusive group of $31.3 \%$ and in the control group had a history pembersian exclusive breastfeeding of $18.8 \%$. History Award food companion of breastfeeding in case group is not as recommended $62.5 \%$, in the control group a history of giving breast milk as recommended by $76.6 \%$, a history of infectious diseases in the case group was $75 \%$, whereas the control group did not have a history of infectious diseases amounted to $59.4 \%$. Nutritional intake is less in the case group showed $68.8 \%$, whereas in the control group good nutritional intake of $46.9 \%$. Incomplete immunization status in case group amounted to $50.4 \%$, in the control group had complete immunization status amounted to $70.3 \%$. Family economic status is less (lower) in the case amounted to $56.3 \%$, in the control group of high economic status amounted to $62.5 \%$.

2) There is a history of the relationship mother ate during pregnancy with the incidence of stunting. History mothers eat well during pregnancy less, a smaller risk for the incidence of stunting in infants than mothers with a history of eating less during pregnancy

3) There is a history of exclusive breastfeeding relationship with the incidence of stunting, a history of exclusive breastfeeding is less risk for the incidence of stunting compared to the non-exclusive breastfeeding

4) There is a relationship history of giving complementary feeding and the incidence of stunting, History of giving breast milk is not suitable for events organized by the risk of stunting 5 times bigger than with infants compared with a history of giving complementary feeding as directed.

5) There is a relationship with the incidence of infectious disease history stunting., a history of infectious diseases which had suffered a risk of stunting 4 times greater compared with patients with no history of infectious diseases

6) There is a relationship of nutrient intake with the incidence of stunting. Nutritional intake is less risky for

\section{Volume 5 Issue 7, July 2016 www.ijsr.net}




\section{International Journal of Science and Research (IJSR) \\ ISSN (Online): 2319-7064}

Index Copernicus Value (2013): 6.14 | Impact Factor (2015): 6.391

stunting occurs in infants three times greater with good nutritional intake.

7) Immunization status associated with the incidence of stunting in children under five. Incomplete immunization status have arisk of stunting occurs 3 times larger than the complete of immunization status in toddlers

8) There is a relationship of economic status of families with incidence of stunting, low economic status families at risk of stunting occurs three times greater than the high economic status.

The Conclution and Recommendation Based on the research, we can suggest the following as:

1) The need for nutritional handler that starts from the time of conception to the first until to second years (1000 the first day of life through the provision of nutritious food and nutrition behaviour coaching household level.

2) 2 .The need for nutritional treatment at an early age group after handling one thausandthe first day of life(1000 FDL) in the group of children with coaching and mentoring early childhood at the family level in order to create independent family nutrition.

3) The need for regular monitoring of the nutritional status of each quarter, as the basis of an evaluation program in 1000 the first day of life handling household level as well the handling of infectious diseases continuously and sustainably through accelerated with Precaution and an infectious disease program and $\mathrm{MCH}$ programs as well as health promotion.

4) The need for food diversification program in assisting the family and establish nutritional prosperous family that integrate with agriculture, the coordination familly plans national(CFPN) and The administration of the village .

\section{References}

[1] ACC/SCN, 1997, " 3 nd Report on The World Nutriton Situation”, Geneva, Diaksespada 20 Februari 2015 dariwww.uncn.org.

[2] -------, 2000, " 4 nd Report The World Nutrition Situation, Nutrition Throughout The Life Cycle" Geneva, Diaksespada 15 Januari 2015 dariwww.unscn.org

[3] Achsin, A, et all, 2003, UntukmuIbuTercinta, Edisi 1, Bogor, Prenada

[4] Ahmed, T., et.all, 2012, Nutrition Of Children And Women In Bangladesh : Trend And Direction For The Future, Bangladesh, Journal Of Health, Population and Nutrition, Diakses 10 Maret 2015 dariwww.ijcn.or.id

[5] Almaisier,S, 2002, Prinsip Dasar Ilmu Gizi, Gramedia Pusaka Utama, Jakarta

[6] -------------(ed), 2005, PenuntunDiitedisibaru, Jakarta, GramediaPustakaUtama

[7] Anggraeni, A. C., 2012, Asuhangizi : Nutritional Care Process, Edisi 1, Yogyakarta, Grahallmu

[8] Arisman, 2004, GiziDalamDaurKehidupan, PenerbitBukuKedokteran EGC, Jakarta

[9] Assis, AMO, et.al, 2004, " Childhood Stunting in Northeast Barzil : The Role Of SchistosomaMansoni Infection And InadequteDiatary Intake", European Journal Of Clinical Nutrition (2004). 58, 1022 - 1029, Diaksespada 15 Januari 2015 dariwww.ijcn.or.id
[10] Astari, L. D. A. Nasutiondan C. M. Dwiriani, 2005, HubunganKarakteristikKeluarga,

PolaPengasuhandanKejadian Stunting AnakUsia 6 12 Bulan" Media GizidanKeluarga 29 (2): 40-46, $\begin{array}{llll}\text { Diaksespada } & 2 & \text { Januari } & 2015\end{array}$ dariwww.repository.ipb.ac.id

[11] BadanPenelitian PengembanganKesehatanDepKes RISKESDAS Tahun 2010, Jakarta

RI, $\quad 2010$

[12] Badan Penelitian dan Pengembangan Kesehatan Departemen Kesehatan RI. 2013, Laporan hasil Riset Kesehatan Dasar 2013, Jakarta

[13] Bappenas, RI., 2010, LaporanTujuan Pembangunan Milenium Indonesia, 2010,KementerianPerencanaan Pembangunan Nasional/ BadanPerencanaan Pembangunan Nasional (BAPENNAS), Jakarta

[14] BAPPENAS, 2011, RencanaAksiNasionalPangan Dan Gizi 2011-2015, KementerianPerencanaan Pembangunan Nasionan, diaksespada 22 Februari 2015 darihttp: //kgm. bappenas. go. Id / document/datadokumen/40-datadokumen.pdf.

[15] Brown, J, E. et.all, 2011, Nutrition Throught The Life Cycle, Fourth Edition Wadsworth, di aksespada 3 Maret 2015 dariwww.ijjen.or.id

[16] Beaglehole R., Bonita R danKjellstrom T., 1997, Dasar-DasarEpidemiologi, GadjahMada University Press, Yogyakarta

[17] Brooks, J., 2011, The Process Of Parenting, Edisi 8, Yogyakarta, PustakaPelajar

[18] Budianto, 2009, Dasar-DasarIlmuGizi, UMM Press, Malang

[19] DepKes RI,, 2006, PedomanPraktisTerapiMedis, DirektoratJendralBinaGiziMasyarakat, Jakarta

[20] Engle, P. L., Menoe P. \&Hadda, L., 1997, Care And Nutrition Concepts And Measurement, Washington, D. C. International Food Policy Research Institue, Journal Health Of Nutrtion Research, diakses 4 April 2015 dariwww.ijsk.or.id

[21] Friedman, M.M, 2010, Keperawatankeluarga(Hamiid A.Y.S, dkk, penerjemah) Riset, TeoridanPraktek, Edisi 5, Jakarta, EGC

[22] Jurdarwanto, W., 2004 , MengatasiKesulitanMakanPadaAnak, Jakarta, PustakaSwara

[23] Kaakinen, et.all, 2010, Family Health Car Nursing, Theory, ParcticeAnd Research $4^{\text {th }}$, Edition, Philadelphia, FA Davis Company

[24] KementerianKesehatan RI, 2010, RisetKesehatanDasar, BadanPenelitian Dan PengembanganKesehatah, Jakarta.

[25] -------------, 2013, PedomanPerencanaan Program GerakanNasionalPercepatanPerbaikanGiziDalamRan gkaSeribuHariPertamaKehidupan (Gerakan 1000 $H P K), S U N$, diakses 12 Maret 2015 darihttp:// www/

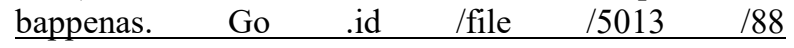
/48/0466/pedoman_SUN/10sept_2013.pdf

[26] -----------, 2007, KeputusanMenteriKesehatan RI No. 224/Menkes/SK/II/2007 tentangSpesifikasiTekniksMakananPendamping ASI(MP-ASI) bubukInstanUntukBayi $6 \quad-\quad 12$ bulan(serial online) 2007, diakses 10 Februari 2015 darihttp://gizi.depkes.go.id 


\section{International Journal of Science and Research (IJSR) \\ ISSN (Online): 2319-7064}

Index Copernicus Value (2013): 6.14 | Impact Factor (2015): 6.391

[27] ---------2010, StandarAntropometriPenelitian Status GiziAnak,DirektoratJenderalBinaGizi Dan KesehatanIbu Dan Anak, Kemenkes RI

[28] Kurniasih, dkk, 2010, Sehat Dan BugarBerkatGiziSeimbang, Jakarta, Gramedia

[29] Lemesshow S., Hosmer D., Klar, 1997, Adequacy Of Sample Size In Health Studies (Terjemahan) :Purnomo D., Yogyakarta, UGM Press

[30] Matsithah, T., Soekirman, Martianto, D., 2005, HubunganPolaAsuhMakandanKesehatanDengan Status GiziAnakBalita Di DesaMulyaHarjo, Bogor, Media GizidanKeluarga, 29, 29-30

[31] Sulistyoningsih H., 2011, GiziUntukKesehatanIbu Dan Anak, Grahailmu, Jakarta

[32] Supariassa IDN, BachtiarBakridanIbnuFajar, 2002 Penilaian Status Gizi,PenerbitBukuKedokteran EGC, Jakarta

[33] Scalling Up Nutrition, Sculling Up Nutrition (SUN) Movement Strategy 2012 - 2013.(cited 2013 April 26) Available from URL: http://scallingupnutrtion.org/wpcontent/uploads/2012/SUN-MOVEMENTSTRATEGY-ENG.pdf

[34] Semba RD, et.all, 2008, Effect Of Parental Formal Education On Risk Of Child Stunting in Indonesian And Bangladesh : a Cross-Sectional Study, Lancet.Diakses 7 Maret 2015 dariwww.ijsk.or.id

[35] World Health Organization(WHO), 2012, World Health Statistic, 9cited April 26 ${ }^{\text {th }} 2015$ )

[36] Availablefrom URL : http:// www. who.int /gho/ bliccations /world health statistic/ EN WHS2012 full.pdf 